\section{Doing Research in a Conflict Situation Encounters and Experiences}

\section{Suresh Dhakal}

\section{Abstract}

Fieldwork, an anthropologist's vocation, is full of tensions and dilemmas. However, the experiences of any or all tensions, troubles and even failures are a 'source of ethnographic knowledge in themselves'. During the fieldwork for my PhD research, I encountered several such incidents, which have made my work more interesting and my experience richer. This article describes the situation of doing fieldwork in the conflict period, when the 'peace process' was not yet come to the conclusion.

Keywords: ethnography, fieldwork, conflict, ethics, peace-process

\section{Introduction}

Fieldwork, an anthropologist's vocation, is both a mandate and passion for him; although, he knows that his vocation is full of tensions and dilemmas. However, the experiences of any or all tensions, troubles and even failures are a 'source of ethnographic knowledge in themselves' (Slukka 2007). In this article, I present an anecdotal narrative based on my unanticipated encounters and experiences during the fieldwork I had carried out fieldwork for my $\mathrm{PhD}$; in an eastern Tarai village of Nepal.

I already had decided to carry out the fieldwork in a particular district as ; however, I had not located a particular village or area for a prolonged and in-depth study. I was still travelling around to locate myself in a more 'ideal' site. I went around several VDCs in 3 weeks time before I finally selected a particular village for the fieldwork.

During the entire fieldwork, I encountered several such incidents, which have made my work more interesting and my experience richer. However, in this article, I have described the situation of doing fieldwork in the conflict period, when the 'peace process' was not yet come to the conclusion.

\section{The Encounter}

It was late November 2006. This was the time when Nepal Communist Party (NCP) Maoist and Seven Party Alliance (SPA) had just signed Comprehensive Peace Agreement (CPA) a couple of weeks ago on November $8^{\text {th }}$ of the same year. Before, on October 29, NCP Maoist had extended the ceasefire by three months. And, NCP Maoist and SPA, both were affirmative about arms management accord. Hence, peace process was on its way. I thought this was the perfect time to go to Morang to begin the fieldwork.

Once, I was on a motorbike, heading towards the village. It was a dirt road, which had become muddy due to water flown out of side canal; therefore, bike was hustling in a snail's pace. I had just passed the blacktopped road and took dirt road in search of an ideal field site. All of a sudden, two or three men appeared in the middle of road and blocked the way. I had to stop my bike in no time. I stopped the bike but was still on. One of the men switched off the bike and immediately snatched the key and gave to another man. He then asked me to get off the bike. I did. I hardly could say anything, as it all happened so abruptly. They seemed so rude and I could read their anger on their face. I assumed they all were around 25-30 years of age. One of them had a cotton bag-pack looked like a schoolbag on his right shoulder. I could see something pointed and gun shaped object inside his bag. I could guess, based on my previous experiences that was a gun; and, which was enough to unnerve me. 
I was confused why they were doing so to me. A local Tharu boy travelling with me, who was my contingent field assistant, also could not say anything. He also seemed confused and terrified. He later told me that he could recognize them, but did not dare to talk to them. I identified them as local Maoist cadres, but could not be a hundred per-cent sure yet. One of the men, with that cotton bag with a gun shaped object, looked like a leader among them, ferociously asked,

"Who gave you a permission to enter into the village? Don't you know this is our territory? Teti pani thaha chaina hamro satta antargat ko bhugol ma prabesh garna anumati chahinchha bhanera? (lit. Don't you know that you got to get permission to enter into the territory under our authority?).

Only then I was sure that they were Maoist. I was worried as they for sure were going to give trouble. My contingent field assistant, a Tharu man, tried to say something, but he was ruled to keep his mouth shut. "Better you do not get involve here, don't even dare to speak a single word”.

I tried to be unruffled. And, with an uneasy smile, I spoke in a soft voice introducing myself,

"My name is Suresh Dhakal. I teach in the University; now doing PhD. I am here in the village for the field research. Today we are going to Motipur just to have an idea about the village. We are not government people or from any development organization”.

He looked more awed. There were already a few people gathered around. Nobody spoke anything rather watched anxiously, as if something is going to happen soon. A few passers-by stopped, and without bothering to ask anything, continued their way. The leader like man growled,

"When people approach closer to the victory, the reactionaries, agent of imperialist, enter into the village in the different guise... in the name of researcher, development worker... who do not know that reactionaries are terrified and want to disrupt the progression towards people's victory”.

When I tried to explain him that I have nothing to do with this politics at the moment and my intention was purely academic, but he was not going to listen to me. As crowd was growing, he almost shouted,

"No one exists against our glorious party, it is built upon the sacrifice of thousands of our great martyrs,

and no one ever dare to conspire against people...”

He continued. I did not see any relevance and meaning of his shouting. I was little bit nervous, little bit terrified, and little bit angered. But, I could do nothing; even express any of my feeling. I was still looking for ways to negotiate with him.

I told him that I sometimes had written in the papers, even supporting the people's movement. I intentionally spell the name of a news magazine, Mulyankan, I occasionally used to write for that magazine and that was then considered as closer to the NCP Maoist. But, it could not produce any effect on him. I suspected he even had heard of Mulyankan.

I tried something else. I reported him that I even have got a formal letter from the university. "Who could not understand such a trick to fool the people?” He seemed to be uninterested listening any of my argument. I politely asked him, "What is then? What do you want me to do?" He replied in no second, "Go back and get the permission from our office to enter into the territory under our authority, otherwise, get back to where you were from”.

But he refused to give me my bike back. He shrugged his both the shoulders and 'declared', "People's property, people would use it".

I was full of anger but undecided what to do and what not.

"May I know who you are?" I thought he would be angry on this question. But he was not. He introduced himself as, Amar, and identified him as a political commissar of that Ilaka (area).

I stretched my hand forward to shake hand with him. I was trying to be acceptable to them. Fortunately he did the same. "I am 
happy to meet you”, I said. Then, I felt conversation became easier. I could see, he sounded a bit mild. We were still in the middle of the road.

By some chance a local youth Tusli, whom I knew for sometimes, arrived on a bicycle. He got off his bicycle, and greeted me with 'sir namaste!' and shook hand with Amar and one or two others. He was from the same village, and I knew him a couple of weeks ago. But he was a district member of Tarun Dal, a youth wing of Nepali Congress. Therefore, I became suspicious if my knowing to Tulshi might produce any adverse impact. He did not have any clue what was going on there. My field assistant said something in Tharu language. Then Tulshi said something to Amar. But, he pronounced his name as Vijaya not Amar. He was not afraid when he was talking to Vijay, alias Amar. I gained some confidence that Tulshi would resolve the case and rescue from the difficult situation.

Finally, we were told to go to the party office in nearby bazaar, located about $1 \mathrm{~km}$ from there. Tulshi took the key of my bike; now I was in the back seat of bike. He asked my field assistant to take care of his bicycle. Vijaya alias Amar and two others rode on a two-stroke Yamaha bike. I had not noticed that there was another bike nearby. We reached their office. There were about a dozen white plastic chairs and one long bench. There was a heap of bananas, not yet ripe, though. There were couple of men, women already in the office room. They greeted us. I did the same. It was just opposite of what I had experienced half an-hour ago. Vijaya alias Amar gave some instruction to his people. Soon they brought juice made of artificial ingredients in a large plastic jug and Vijaya forwarded bananas.

"Have some; people's property, we share to all, this is what we want others to do, as well”.

I asked to Tulshi, what to be done next. He asked me to be seated for a while. I nodded my head like an obedient child. He was trying to contact someone over his cell phone.

Conversation became more relaxed now. I was trying to convince them I had no intention to harm them at all. At the meantime, I also became slowly attracted to thinking that, if friendship can be established with these people, it would be easier to observe and study the political transition at the local level. During the conversation, I deliberately used the words like, 'ground reality', 'objective condition', 'forms and content', 'forward looking', 'peoples' enemy', and so on. They were the terms common in Maoist lexicon. All Maoists leaders and cadres used to have those words invariably in all their speeches and writings.

He seemed to be bit positive towards me.

Or, maybe it was an illusion.

Tulshi was trying to call someone, and eventually he succeeded. He talked a while in the local Tharu dialect, and then gave his cell phone to Vijaya. He went to backyard of the house while talking over the phone. After a while, he came back, still talking on the phone. He did not seem to be comfortable. He handed over the phone to me. What a miracle! Mr. Chaudhari was in the other end of the phone conversation, a common friend of three of us. He was a development worker with one of the INGOs. Mr Chaudhari told me that I should not worry at all, "everything will be all right. You are safe." He said to me over the phone. I thanked him and sighed. When he said, 'you are safe', I immediately realized that I could have been in the risk. Once again, I felt safe and stress-free again. Probably Vijaya also realised I was in deep fear and now feeling relived, he told me, now almost in a consoling voice,

"We work with the people; we are the one who fight for the people's right. We never make any harm to the people, but we do not let a people's enemy exist. You don't have to be worried about anything. You just have to report us about your work and movement. We help you".

He further said, in a bit apologetic tone,

"We could not study further. We are in people's university now, and we need people like you in the future. We can learn from people's like you...” 
What a twist in the story! It was all like a dream, so dramatic. I did not complain anything against them, rather told them I would be in touch and meet them in the future, too. I told them that I might need their help. It was a revelation of the basic truth in fieldwork that 'what members of a society know, think and do in dealing with everyday circumstances' constructs and continually produce and reproduce the social reality; therefore, 'social order is a methodologically generated products of members of society' (Bergmann 2004).

\section{The Circumstance}

The circumstances that produced a particular social situation, that I encountered, were never thought well before to that extent. Maoist Army, PLA, was not yet into the cantonment. They had a temporary military camp of Maoist in the VDC that I was going to visit, which I was unaware of. Actually after a couple of days of that incident, on November $28^{\text {th }}$, the NCP Maoist and government had signed the arms management accord.

Later they clarified the circumstance. They thought I was also with the INGO (a particular INGO, whose name is not disclosed here). The INGO was recently expanding its working areas in some of the VDCs of that area. Vijay alias Amar explained to me that the INGO people did not seek the permission from CPN Maoist, rather entered the VDC without prior notice to them. They were unhappy with that INGO. They had made a local strategy not to allow any of its staff entering into the village.

I did not bother whether their presumptions were right or wrong. Rather, I realized that this is the kind of situation that I might have to encounter in the days to come, too. This reminded me what Berrman long ago narrated his experience, "As in all field work, the choices were not always mine and the results were frequently unanticipated" (Berreman, 1997, p. xviii).

\section{Some Reflections}

My first encounter in the field, thus, imposed me a question of my integrity of a researcher. How could have I presented to them, at the first place? How could I keep communication with them, but not to influence or interfere on my work? Who was Mr. Chaudhary, a man I knew only as a development worker? Should I continue meeting with them in the future or should I avoid them? This could have been important for me, as "the nature of the data...largely determined by the identity as seen by the subjects” (Berreman 1997).

I was sure that one of the questions that I have to face time and again was my political affiliation, as they were always 'curious' about this. What kind of relation should I maintain with them? How could I maintain my political neutrality, if not ideological neutrality during the entire fieldwork period? How could I present myself was as I was? This was, in many ways, linked to the ethical question. However, at the end of the fieldwork, I realized I was able to maintain my political neutrality. People might have their opinion about me, but neither had they ever expressed nor did I encounter any odd behaviour from them due to their perception about my political affiliations.

There was an office of Young Communist League (YCL), youth wing of NCP Maoist, in between my local residence and the village centre, where I used to visit everyday. They had occupied an office of a government irrigation project. Bir was the commander of that camp and he was from my study village. There were about 20 people living in that compound. Sometimes there used to be more people and some other times that used to be almost empty. Later, I knew that they were conducting prasikhyan, the political orientation program, in different places, and sometimes they used to gather in that place, too. The Seven Party Alliance (SPA) used to call YCL as a quasi-military structure. That was. I used to stop by their, meet and talk to Bir, the commander, sometimes for hours. He had also offered me the meals there once or twice. So, for me that was a part of ethnography, and Bir and others were very useful informants for the research that I was conducting. When, other Maoist cadres saw me in 
their office, and chatting with their commander, they were also hospitable to me, and used to come and shake hands when they met me in the market or in any public place. In that sense, people supporting Maoist were sympathetic to me. I thought so.

But, on the other hand, I could maintain very cordial relationship with the NC and UML. I had to talk many of them frequently as most of them were also holding different posts and position in the organisations that I was studying.

N.R. Giri was a high school teacher but at the same time UML district committee member, too. He was affiliated with the UML since very beginning. He could also relate himself with the Jhapa Bidroha, Jhapa Uprising, armed struggle against 'landlords' led by group of communist who were inspired by the similar armed struggle of Naxelite movement of India in early 1970s. Following on my knowledge and information, I was eager to know more on this also. Therefore, I spent hours with him, repeatedly also talking about his party affiliation and the impact in that particular VDC. As I was aware of some of the historical facts of that upsurge, he also found me interested on his matter. Probably, he might have thought that I was also from the same ideological school as he is. Thus, UML people also equally helped me during my stay in the village.

Once, I asked one of the schoolteachers and a graduate in management from TU, to compile the members of different Community Organisations (CO). He had become a friend of mine and was also eager to help me in my research. When I went back to the field after some days break, one of the COs chairperson, Manju asked me if I had assigned some job to Mr. Bhattarai. I said I did. She told,

"You could have told us before. He came and asked to give the details, but we did not believe him, as he is a Maoist, so we did not give our minute to him". Manju was a UML cadre, also represented UML in the VDC, as a woman member. Then, I realised some of them found me not as a Maoist supporter, rather a UML supporter.”
It was around mid-April of 2007. K Chaudhari and Pakkhulal ji, both Nepali congress leaders of that village, met me in the teashops, and invited me to join them in a picnic in a following week.

"We have organised a small program, it is in honour of newly elected district committee chairman and others, so we want you to come. This is organized by us local congress cadres”.

It could be fun and could be useful, too. But, why they were inviting me in a congress party picnic. I wondered if they also thought me as one of them! Is this the result of political neutrality I wanted to maintain?

\section{Conclusion}

We consider doing anthropology, thereby the ethnography is a 'moral act', and then it necessarily involves the question of 'ethics'; of “moral dimension” (Herdt, 1988, p. 185 quoted in Tedlock 1991). Individual integrity rather than institutional arrangements is more instrumental in maintaining the ethics in qualitative research.

Therefore, doing ethnographic fieldwork in a politically divided society, in addition to already stratified nature of it, is emerging as a challenge to anthropologists, more so to the natives ones. In this case, too, it was not easy to maintain 'ideological' neutrality, as in the course of several formal, informal conversations I had to participate and give my opinion about certain issues. I was, however, sympathetic to all the parties, as well as critical. Based on such positions, probably, they did not think me as others. I however kept telling them time and again that I was not affiliated to any particular party and my position was neutral in the field throughout. I consistently maintained my honesty and integrity. I did not lie or otherwise to please the people and to get the information. What Wax (1971) advised some four decades ago is still advisable, as she offers advice to 'anticipate and confront the experiences and accidents of fieldwork with good nature, fortitude, and common sense.' If we wish to gain an understanding of 'how human lives "make sense" within 
the context in which they live' (Davies and Spenser, 2010), then we Wax advice is a welcoming one. It is equally important to note that 'fieldwork consist of a particular form of living rather than a set of methods' (Hsu 2010).

Finally, my experience also approved Tedlock (1990) when he maintained "there has been a shift in cultural anthropological methodology (beginning in the 70s) from participant observation toward the observation of participation. During participant observation ethnographers attempt to be both emotionally engaged participants and coolly dispassionate observers of the lives of others. In the observation of participation, ethnographers both experience and observe their own and others' co-participation within the ethnographic encounter".

\section{Reference}

Bergmann, J.R. (2004). 'Ethnomethodology’ (pp.72-80). In Uwe Flick, Ernst von Kardoff and Ines Steinke (eds.) A Companion to Qualitative Research. London: SAGE Publications.

Berreman, G. (1997). Hindus of the Himalayas: Ethnography and Change. Calcutta: Oxford University Press. First published, University of California Press (1963).

Davies, J. and Spencer, D. (eds.)(2010). Emotions in the Field: The Psychology and Anthropology of Fieldwork Experience. Stanford: Stanford University Press.

Dhakal, S. (2012). Democracy in Everyday Life: Ethnography of Participation and Representation in an Eastern Tarai Village of Nepal. An Unpublished PhD dissertation.

Hsu, E. (2010). 'Tian'anmen in Yunnan: Emotions in the Field during a Political Crisis' (pp. 155-170). In Davies, J. and Spencer, D. (eds.)(2010) Emotions in the Field: The Psychology and Anthropology of Fieldwork Experience. Stanford: Stanford University Press.

Sluka, Jeffrey A. (2007). 'Introduction: Fieldwork Conflicts, Hazards, and Dangers Introduction'. In Antonius C. G. M. Robben and Jeffrey A. Sluka (eds.), Ethnographic Fieldwork: An Anthropological Reader' MA: Blackwell Publishing Ltd.

Tedlock, B.(1991). 'From Participant Observation to the Observation of Participation: The Emergence of Narrative Ethnography'. Journal of Anthropological Research, Vol. 47, No. 1 (Spring, 1991), pp. 69-94

Wax, Rosalie (1971). Doing Fieldwork: Warning and Advice. Chicago: The University of Chicago Press. 